\title{
Food and Economic Security through Homestead Vegetable Production by Women in Flood Affected "Char" Land
}

\author{
Shaikh Shamim Hasan ${ }^{1 *}$ and Sabina Sultana ${ }^{2}$ \\ ${ }^{1}$ Department of Agricultural Extension \& Rural Development, BSMRAU, Gazipur, Bangladesh. \\ ${ }^{2}$ ATI, Gazipur, Bangladesh
}

Corresponding author and Email: shamim.aer@bsmrau.edu.bd

Received: 04 January 2011

Accepted: 26 November 2011

\begin{abstract}
The study was conducted in several "Chars" (Char Kachadia, Char Gangaproshad, Char Alokdia and Char Tishondi) in Shibalaya Upazilla under Manikganj District to: investigate the livelihood situation and socio-demographic characteristics of the Char women, identify the current crop production practices adopted by them and to highlight the most likely months for food insecurity along with main problems regarding homestead vegetable production by the respondents. A total of 150 respondents were selected using simple random sampling technique. The study was conducted during August 2009 to February, 2010. It was revealed that most of the respondents were middle aged, had medium to big families, were mostly illiterate to having primary education. They had an average homestead vegetable farm of 6.71 decimals. It was found from the study that most of the respondents spent 3.20 hours/day for cultivating vegetables in their homestead areas. Different types of vegetables were being grown by the respondents including spinach, bitter gourd, cowpea, pumpkin, okra, water spinach, pointed gourd in the summer season and red amaranth, brinjal, tomato, bean, radish, pepper in the winter season. All these vegetables provided food security as well as economic security to the respondents who pointed out that March and September were the most food insecure months. The findings also indicated that the respondents faced several problems like lack of capital, lack of irrigation water during dry season and lack of good quality seeds.
\end{abstract}

\section{Keywords: Food and economic security, homestead, vegetable production, char land}

\section{Introduction}

Bangladesh is predominantly an agricultural country with the sector accounting for $18.64 \%$ of the country's GDP and employing around $62 \%$ of the total labor force (Anonymous, 2009). In spite of recurrent natural calamities, the country has achieved impressive gains in food grain production in the last two decades and reached to near self-sufficiency at the national level by producing nearly 28 million metric tons of cereals, especially rice and wheat (Anonymous, 2009).

Malnutrition among the rural poor in Bangladesh is probably the highest in the world. $46 \%$ of under five children were under weight and $36 \%$ of mothers were chronically energy deficient (HKI, 2010). According to a WFP (2008) report, 60 million people in Bangladesh still do not have sufficient food to eat and the country has the highest child underweight rate in South Asia and one of the highest in the world. Millions of children and women are suffering from one or more forms of malnutrition including low birth weight, stunting, underweight, vitamin A deficiency, iodine deficiencies disorder and anemia (UNICEF, 2009). About 25\% of the population lives in extreme income poverty. The food security of this group of people worsens during the monsoon season. 
The usual diet lacks micronutrients and diversity due to low access and limited availability of both plant and animal sources foods to meet nutritional requirements (HKI/IPHN, 2006b). The condition looks more serious in the Char lands of Bangladesh particularly at the time of flood. The riverine sand and silt landmasses, known as "Char" in Bengali are home to over a million people in Bangladesh. Char communities are constantly under threat from both ecological and socio-economic disasters. Char dwellers are considered poorer than the main land population and are vulnerable to flooding. Malnutrition and micronutrient deficiency rates are higher in the Chars then anywhere else the country. Food based strategies, including homestead food production through homestead vegetable production program not only increase food security but also have an impact on reducing micronutrient deficiencies and women empowerment as well as their economic security (HKI/IPHN, 2006a).

At the household level, food security refers to the "ability of the household to secure, either from its own production or through purchases, adequate food for meeting the dietary needs of its members. Approximately $7 \%$ area $(0.53$ million ha) of the total 8.4 million ha of cultivable land in Bangladesh is occupied by homesteads. The size of homestead varies depending on geology and farm size. The size of homestead ranged from 0.027 ha in flood plain area to 0.031 in Char land (Anonymous, 2005).

Women and girls of Bangladesh suffer most during the pre-harvest period when households go through food rationing. Women usually eat after all household members have had their share which seriously affects the adequacy of their nutrient intake. This custom causes them to have a smaller share of rich food or even none at all. During normal periods, households try to consume staples (rice and wheat) from their own production and or purchases from the market with their earnings. For vegetables, all households rely on their own production at or around the household premises and purchase from the market.

During the time of flooding the condition of the affected people is changed. After flood the male members of the vulnerable family are much busy with cultivating staple foods in the fields. But the women members of the family perform various economic activities concentrated to their homestead like vegetable production, poultry rearing, animal rearing etc. By this way they try to give some additional nutrition to their family that gives some food security as well as economic support. Vegetable cultivation is very labor intensive. Women have to plant, weed and irrigate, sometimes apply pesticide for pest control and harvest the vegetables. By this way they usually upgrade their skills which in turn have proved to increase women's income resulting in better use of household resources, improved caring practices and empowerment. Through utilization of local resources and low cost technologies household food security and livelihoods can be improved. The study was therefore undertaken with the following Objectives:

1. To determine the socio-economic status of the women of the concerned study area;

2. To ascertain the present situation of the homestead vegetable production;

3. To identify food insecurity period with coping mechanisms and problems regarding homestead vegetable production.

\section{Methodology}

Shibalaya Upazila of Manikganj District was selected purposively as the study area. Since many Chars are found here. Out of these Chars, 04 Chars namely Char Kachadia, Char Gongaproshad, Char Alokdia, and Char Tishondi were selected as the locale of the study. Total population in the selected Chars was 11012. Out of this, 150 women were selected as the sample following simple random sampling technique. 
For an in depth study related to livelihood strategies, poverty dynamics and coping mechanisms of the Char people, survey method was applied. For this purpose an interview schedule was prepared considering the objectives in view. Personal interview was conducted with all the 150 respondents using this interview schedule. Simple statistics like percentage, mean, range etc were calculated.

\subsection{Measurement technique}

Age of the respondents was measured in terms of years on the basis of her response. A score of one was assigned for each year of age. A score of one (1) was given to a respondent who has completed one year of schooling. A score of zero (0) was assigned to an illiterate respondent who could not read and write at all. A respondent who could sign her name only, her educational qualification was considered equal to one year of schooling and was given a score of one. Family size included all members of a household like husband, wife, children and other members who were living together in a family. Family size of a respondent was measured by assigning a score of one (1) for each member of the family. Farm size was estimated on the basis of the cultivated area either owned by a farmer or cultivated on share cropping, the area being estimated in terms of full benefit to the respondents. The total area of land thus obtained was considered as the farm size (in terms of decimals) score of the respondent. Homestead vegetable farm size was also calculated as like as farm size of the respondents. Income from different sources was measured as the amount of money earned by a respondent from different sources. It was expressed in BDT. Training exposure of the respondents was calculated by giving a score of 1 to every participation of one training and zero (0) was given to no participation of any training. The daily time allocation in different works was meant for the approximate daily time utilization in different works like in different homestead domestic work and homestead vegetables production. A score of one (1) was given for each hour of work with different activities.

\section{Results and Discussion}

\subsection{Personal Characteristics of the respondents}

Table 1 shows that average age of the respondents was 35.61 years and the observed range was 25-50 years. The respondents had an average level of lower primary education. The literacy of the farmers is an important factor, which determines their communication behavior. More particularly, it allows one to have access to the print media. Char lands are situated in distant places and the condition of those areas are very much different than those of main lands. So shortage of educational institutions was found in Char lands. At the same time most of the people of the Char lands particularly are poor and find it difficult to go to any educational institutions.

Table 1. Personal characteristics of the respondents

\begin{tabular}{lcc}
\hline Variables (unit) & Mean & Observed range \\
\hline Age (years) & 35.61 & $25-50$ \\
Level of education & 2.29 & $0-7$ \\
Family size (number) & 6.32 & $4-10$ \\
Farm size (decimals) & 15.55 & $8-55$ \\
Homestead vegetable farm size (decimals) & 6.71 & $4-15$ \\
Income source (BDT) & & \\
a. Agriculture & 28379.33 & $8000.00-60000.00$ \\
b. Business, service and cattle rearing & 9176.00 & $1000.00-40000.00$ \\
c. Total income & 37555.33 & $8000.00-70000.00$ \\
\hline
\end{tabular}


On an average, the respondent's average family size was 6.32. Their average farm size was 15.55 decimals. The average vegetable farm size was 6.71 decimals. This unit area was occupied by the respondents to grow different types of vegetables all over the year which gave them food and nutritional security to some extent.

According to Table 1, the average agricultural income of the respondents ranged from 8000.00 BDT to 60000.00 BDT, with an average being 28379.33 BDT. On the other hand, average other income source like small petty business, service, and cattle rearing was 9176.00 BDT. At the same time total average income of the respondents of the study area was 37555.33 BDT. As the lands of Char areas are fertile, farmers had enough agricultural products from their lands as well as from their homestead areas and they utilized these for maintaining their family. But some farmers cannot produce enough to support their family needs and eventually arrive at a vulnerable situation.

\subsection{Training experience on vegetable production}

In Char lands women have less access to extension services and vocational training, credits and technologies. Char lands are situated in distant places and most of them are treated as vulnerable areas. So farmers had little opportunity to take part in different training programs. The case for women to take part in training program was also very poor. Although $14.7 \%$ of the respondents had training experience on vegetable production and related issues (Table 2), the training was one day mostly and about $85 \%$ respondents had no training.

This shortage of training exposure reveals that it is very difficult to transfer different modern and high yielding varieties of vegetables as well as their management technologies to those Char areas, especially to those homestead vegetable growers. If some training programs can be arranged in those areas along with inputs , especially for the women then the production of vegetables can easily be upgraded.

\subsection{Daily time allocation in different work}

Women as producers of food and livestock as well as primary meal makers have important responsibilities to ensure household food security. As primary managers of livestock, women contribute to supply of high-quality protein to the country. Women dominate home garden production and thus improve the variety and quality of the family diet. Table 3 shows distribution of the respondents according to average time spent per day.

Table 2. Distribution of the respondents according to their training exposure

\begin{tabular}{ccc}
\hline Category & Frequency & $\%$ \\
\hline No training exposure & 128 & 85.3 \\
Training exposure & 22 & 14.7 \\
\hline
\end{tabular}

Table 3. Distribution of the respondents according to average time spent per day

\begin{tabular}{lc}
\hline \multicolumn{1}{c}{ Category } & Average time spent (hour/day) \\
\hline Homestead domestic work & 6.48 \\
Homestead vegetable production & 3.20 \\
\hline
\end{tabular}


It is revealed that women of the study area spent 6.48 hours/day on an average for their homestead domestic work. On the other hand, they spent 3.20 hours/day for homestead vegetables production. By utilizing this time they produce different types of vegetables year round.

\subsection{Production of vegetables by the respondents}

Related issues of the vegetables which were cultivated by the respondent women of the study area are discussed below:

\subsubsection{Land type and soil fertility}

The Chars were categorized into three major types by levels i.e., high, moderate and low. High lands are comparatively better for settlement and cultivation, which are located almost in the middle of the Chars. In terms of proportion the amount of moderate land is more than that of high and low land. Moderately high lands are mainly used for cultivation with some settlements. Very low lands are located mostly at the edge of the Chars and are used as grazing land or remain fallow. Three different types of soils are found in the Chars. Those are sandy, clay and sandy clay. Out of these different soil types, the proportion of sandy clay was higher than other two categories with poor water holding capacity. And thus, shortage of water is a common in crop fields of the study area.

\subsubsection{Production season of vegetables in homestead area}

Many vegetables varieties are cultivated by the women of the study area all over the year. All these vegetables gave them food and economic security to some extent. A fairly large number of vegetables are grown in the homestead areas of the respondents of the sample Chars across the two cropping seasons - Summer and Winter. Table 4 shows different vegetables which are grown in the homestead areas of the respondent women in the study area.

Table 4. Distribution of different vegetables grown in the study area

\begin{tabular}{l|l|l}
\hline Vegetables & Summer & Winter \\
\hline Spinach & & \\
Red amaranth & & \\
Bitter gourd & & \\
Brinjal & & \\
Cow pea & & \\
Tomato & & \\
Pumpkin & & \\
Bean & \\
Okra & \\
Radish & \\
Water spinach & \\
Pepper & \\
Pointed gourd & \\
\hline Bottle gourd &
\end{tabular}


Different types of vegetables are grown by the respondents all the year round that is in summer as well as winter season. The main vegetables grown are spinach, bitter gourd, cowpea, pumpkin, okra, water spinach, and pointed gourd in the summer season and red amaranth, brinjal, tomato, bean, radish, and pepper in the winter season. All these vegetables were grown in the homestead area of the respondents and all these are cultivated and managed by the women which gave them food and economic security.

\subsubsection{Production of different vegetables}

A variety of vegetables are grown in the homestead area study site which is cultivated by the women of the respective families. Many vegetables are cultivated by the women all the year round. By cultivating these, they earned some money which they utilized for the betterment of their family. About $77 \%$ respondents cultivated Red Amaranth (Table 5). Average household production of this vegetable was about $33 \mathrm{~kg}$ and average household consumption was $10 \mathrm{~kg}$. Average net income was about 414 BDT. About $90 \%$ respondents cultivated brinjal as they found it was profitable vegetable. Because average household production of brinjal was a about $51 \mathrm{~kg}$ and average net income was 844 BDT. Tomato was an important vegetable of the Char area and about $93 \%$ respondents cultivated tomato. Average production of tomato was $42 \mathrm{~kg}$ and an average of $20 \mathrm{~kg}$ tomato was consumed by the respondents. All the respondents cultivated bean as cultivation of bean is simple and requires less care. The respondents utilized their roofs for cultivating this vegetable.

The respondents earned a good return of about 355 BDT from this vegetable. Spinach is a popular vegetable and cultivated during summer season. About $86 \%$ respondents cultivated this vegetable and collected $70 \mathrm{~kg}$ average household production. The respondents earned about 355 BDT as average net income. According to Table $5,70 \%$ of the respondents cultivated bitter gourd as summer vegetable with production of about $33 \mathrm{~kg}$ and average sale was about $10 \mathrm{~kg}$. Cowpea is a popular crop as it requires less care and less attention. About $84 \%$ respondents cultivated it and earned small return of about 85 BDT. Radish was an winter vegetable and was found to be less important vegetable. The production cost was also higher of about 262 BDT. The respondents earned BDT 625 as average net income from radish. Fifty percent respondents utilized their homestead area for cultivating pumpkin as pumpkin is a popular vegetable of Bangladesh. The average household consumption of pumpkin was about $22 \mathrm{~kg}$ and average net income was 362 BDT. About $46 \%$ respondents cultivated okra during summer season with average net return of 360 BDT.

The respondents also cultivated some other vegetables like Water spinach, Pepper and Pointed gourd in their homestead area to some extent. All these three vegetables were found to be less important as homestead vegetables since these were being cultivated commercially. Actually, homestead areas of the Char people are utilized properly for vegetables cultivation. These vegetables are cultivated and managed by the female members of the family. During food insecurity period the income from vegetables cultivation is an important rescued source. Recently, women in the poor households have been identified as the 'victims' as well as 'managers' of household food security. Women as producers of food and livestock as well as primary meal makers have important responsibilities to ensure household food security. So all these vegetables were played important roles for food, nutrition as well as economic security. 
Table 5. Distribution of average production of different vegetables and related issues

\begin{tabular}{|c|c|c|c|c|c|c|c|}
\hline Vegetables & $\begin{array}{c}\% \text { of } \\
\text { cultiva } \\
\text {-tion }\end{array}$ & $\begin{array}{c}\text { Average } \\
\text { household } \\
\text { production } \\
(\mathrm{kg})\end{array}$ & $\begin{array}{c}\text { Average } \\
\text { household } \\
\text { consumption } \\
(\mathrm{kg})\end{array}$ & $\begin{array}{c}\text { Average } \\
\text { Sold } \\
(\mathrm{kg})\end{array}$ & $\begin{array}{l}\text { Average } \\
\text { Selling } \\
\text { price } \\
\text { (BDT) }\end{array}$ & $\begin{array}{l}\text { Average } \\
\text { total } \\
\text { production } \\
\text { cost } \\
\text { (BDT) }\end{array}$ & $\begin{array}{l}\text { Average } \\
\text { Net } \\
\text { Income } \\
\text { (BDT) }\end{array}$ \\
\hline $\begin{array}{l}\text { Red } \\
\text { amaranth }\end{array}$ & 76.66 & 33.18 & 10.00 & 27.27 & 590.60 & 172.22 & 414.29 \\
\hline Brinjal & 90.00 & 51.87 & 23.13 & 28.75 & 1087.50 & 280.00 & 844.44 \\
\hline Tomato & 93.33 & 42.67 & 20 & 27.78 & 555.56 & 190.00 & 366.67 \\
\hline Bean & 100 & 31.33 & 19.17 & 12.17 & 473.33 & 142.86 & 355.56 \\
\hline Spinach & 86.66 & 70.00 & 19.00 & 50.00 & 500.00 & 166.67 & 355.56 \\
\hline Bitter gourd & 70.00 & 33.33 & 10 & 23.33 & 440.00 & 140.00 & 300.00 \\
\hline Cowpea & 83.33 & 17.27 & 9.58 & 7.69 & 187.50 & 91.67 & 85.71 \\
\hline Radish & 56.66 & 82.50 & 16.88 & 65.63 & 887.50 & 262.50 & 625.00 \\
\hline Pumpkin & 50.00 & 48.33 & 22.22 & 26.11 & 445 & 84.00 & 362.00 \\
\hline Okra & 46.66 & 23.33 & 11.67 & 11.67 & 470.00 & 130.00 & 360.00 \\
\hline $\begin{array}{l}\text { Water } \\
\text { spinach }\end{array}$ & 16.66 & 32.00 & 6.00 & 26.00 & 290.00 & 60.00 & 230.00 \\
\hline Pepper & 20.00 & 1.00 & 1.00 & -- & -- & 50.00 & -- \\
\hline $\begin{array}{l}\text { Pointed } \\
\text { gourd }\end{array}$ & 5.00 & 20.00 & 10.00 & 10.00 & 175.00 & 50.00 & 125.00 \\
\hline
\end{tabular}

\subsection{Food insecurity and coping mechanisms of the respondents}

Food insecurity at household level is one of the most important causes of malnutrition. Household food security depends on having financial, physical and social access and sustainable availability. It means "-----food availability at the national and regional level and stable and sustainable access at the local level were both considered essential to household food security".
As described by the respondents, March is the most insecured month to them followed by February and April (Table 6). On the other hand September was also considered as food insecured period followed by October as mentioned by the respondents. In case of March and April, the day is very long and the family needs more food which they are unable to afford. At the same time, there are fewer homestead vegetable production opportunities during that time. 
Table 6. Seasonal profile of food insecurity of the respondents

\begin{tabular}{l|l|l|l|l|l|l|l|l|l|l|l|l}
\hline \multirow{2}{*}{ Condition } & Jan & Feb & Mar & Apr & May & Jun & Jul & Aug & Sep & Oct & Nov & Dec \\
\cline { 2 - 9 } & & 2 & 1 & 2 & \multicolumn{3}{|c|}{ No food insecurity } & 1 & 2 & $\begin{array}{l}\text { No food } \\
\text { insecurity }\end{array}$ \\
\hline $\begin{array}{l}\text { Food } \\
\text { insecurity }\end{array}$ & & & & & & & & & & & & \\
\hline $\begin{array}{l}\text { Major Income } \\
\text { Generating } \\
\text { Activities }\end{array}$ & $\begin{array}{l}\text { Borrow money from money } \\
\text { lenders, rice husking, earth work, } \\
\text { poultry rearing, begging, selling } \\
\text { livestock and other assets, wood } \\
\text { collection }\end{array}$ & & & & $\begin{array}{l}\text { Poultry } \\
\text { rearing, } \\
\text { rice } \\
\text { husking }\end{array}$ & & & \\
\hline
\end{tabular}

Note: The number in the columns indicates the level of food insecurity where " 1 " is the highest

The respondents of the study area have only a few coping mechanisms to overcome the situation of food insecurity. They borrow money from money lenders and neighbors. Some other coping mechanisms included rice husking, earth work, poultry rearing, and begging. Some male members migrate to other locations for work.

\subsubsection{Problems faced by the respondents regarding homestead vegetable production.}

Six problems faced by the women regarding homestead vegetable production are documented here. The ranking of the problems faced by the women was done based on the number of respondents' opinion in favor of each problem i.e. in respect of each problem; each respondent indicated what extent/degrees the problems were faced by her. Her response was noted in the instrument by putting a tick mark in any of the four columns and was quantified by: very much (4), much (3), low (2) and not at all (1). Then a Problem Index (PI) was computed for each problem by summing the weights from responses of all the respondents against that problem. Problem Index (PI) indicated the extent of problem faced by the respondents. The higher the PI of a problem, the greater was the problem. As there were 150 respondents, PI of any problem could range from $150-600$. On the basis of obtained PI, problems were ranked and are furnished in Table 7.

Table 7 shows that lack of capital was the most important problem of the respondents of the study area. As the people of the Char lands are very poor, the women of the Char lands sometimes faced acute problem to collect capital for cultivating vegetables in their homestead areas. Another major problem of the respondents regarding vegetable production in their homestead areas was lack of irrigation water during dry period which ranked second. Although Char lands are surrounded by rivers there are lack of irrigation water during drier period. Sometimes it is also very difficult for the respondents to collect enough irrigation water by their own as it is a very difficult work. Lack of good quality seeds was another problem which ranked $3^{\text {rd }}$. Char lands are situated in a distant place, so sometimes it seemed to be very difficult for the respondents to collect good quality seeds from distant market. Other problems faced by the respondents were crop damage during flooding period, marketing problems of the vegetables, high production cost which ranked $4^{\text {th }}, 5^{\text {th }}$, and $6^{\text {th }}$, respectively. 
Table 7. Rank order of the problems faced by the respondents regarding vegetable production

\begin{tabular}{llcc}
\hline \multicolumn{1}{c}{ Types of problems } & Obtained scores (PI) & Rank order \\
\hline 1. & Lack of good quality seeds & 480 & $3^{\text {rd }}$ \\
2. & Production cost is much higher & 390 & $6^{\text {th }}$ \\
3. $\quad$ Lack of capital & 540 & $1^{\text {st }}$ \\
4. $\quad$ Lack of irrigation water during dry period & 510 & $2^{\text {nd }}$ \\
5. Marketing problems of crops & 430 & $5^{\text {th }}$ \\
6. $\quad$ Crop damage during flooding period & 460 & $4^{\text {th }}$ \\
\hline
\end{tabular}

\section{Conclusions}

- Seventy eight percent of the respondents of the study area were middle aged women (3045 years) with medium to big (4-10 numbers) family size and most of them were illiterate $(52 \%)$ with limited education of primary level $(41 \%)$ of education. An overwhelming proportion (85\%) had no training exposure in any agricultural topics. At the same time most of the respondent women of the project area had average farm size of 15.55 decimals and homestead vegetable farm size in between 5-10 decimals. It was however, observed that this homestead vegetable farm is an important factor for vegetables production which directly influences food and economic security of the respondents.

- On an average, the respondents spent 3.20 hours/day to produce vegetables. The main vegetables grown by the respondents were: spinach, bitter gourd, cowpea, pumpkin, okra, water spinach, and pointed gourd in the Summer season and red amaranth, brinjal, tomato, bean, radish, and pepper in the Winter season. Bean, tomato, brinjal, spinach, cowpea and red amaranth were the main homestead vegetables in the winter. Average household production of bean, tomato, brinjal, spinach, cowpea and red amaranth were $31.33,42.67,51.87,70.00$,
17.27 and $33.18 \mathrm{~kg}$, respectively. A considerable portion of all these vegetables were consumed by the respondents for their own families which provided food security to them. They also earned some money by selling the excess amount of vegetables which provided economic security to them.

- March and September were the most food insecured months and at that time the respondents borrowed money from money lenders, performed various other activities like rice husking, earth work, poultry rearing, begging, selling livestock and other assets, wood collection as major income generating activities. The respondents of the study area faced some problems regarding homestead vegetable production. Among the problems lack of capital, lack of irrigation water during drier period, lack of good quality seeds were most predominant.

\section{References}

Anonymous. 2009. Bangladesh Bureau of Statistics. Ministry of Planning, Government of People's Republic of Bangladesh, Dhaka, Bangladesh, 147-292 pp.

Anonymous. 2005. Statistical Year Book of Bangladesh Bureau of Statistics. Ministry of Planning, Government of People's Republic of Bangladesh, Dhaka, Bangladesh, $90 \mathrm{p}$. 
HKI. 2010. Homestead food production model contributes to improved House Hold food security, nutrition and female empowerment - experience from scalingup programs in asia (Bangladesh, Cambodia, Nepal and Philippines). Nutritional Bulletin, 8(1): 1-08.

HKI/IPHN. 2006a. Homestead Food Production: The potential and opportunity to improve the food security and rural livelihood in Barishal Division. Homestead Food Production Programme Bulletin No. 3 (April, 2006) 1-4 pp.

HKI/IPHN. 2006b. Homestead Food Production: The potential and opportunity to improve the food security and rural livelihood in Barishal Division. Homestead Food Production Programme Bulletin No. 4 (April, 2006), 1-4 pp.

Huda, E., Naser, A., Rahman, R., Mirza, S. R, Chakrabarti, S. K.and Datta, D. 2006. Participatory Qualitative Survey Report of Char Livelihood Study. PRA Promoters Society, Bangladesh, 03-28 pp.

WFP. 2009. Bangladesh Household Food Security and Nutrition Assessment Report 2009. World Food Program Office, Dhaka, Bangladesh, 1-188 pp. 